\title{
The $\mathrm{ocr}^{+}$Gene Function of Bacteriophages T3 and T7 Counteracts the Salmonella typhimurium DNA Restriction Systems SA and SB
}

\author{
DETLEV H. KRÜGER, * SIGRID HANSEN, AND MONIKA REUTER \\ Institute of Virology, Humboldt University, DDR-1040 Berlin, German Democratic Republic
}

Received 12 July 1982/Accepted 12 November 1982

In host cells containing the Salmonella typhimurium DNA restriction-modification systems $\mathrm{SA}^{+}$and $\mathrm{SB}^{+}$, replication of the $o c r^{+}$bacteriophages $\mathrm{T} 3$ and $\mathrm{T} 7$ is not impaired. However, ocr (gene 0.3) mutants of these phages are susceptible to DNA restriction and modification by the $\mathrm{SA}^{+}$and $\mathrm{SB}^{+}$systems.

Salmonella typhimurium strains code for certain DNA restriction and modification enzymes, of which the systems SA and SB, as well as LT, are best known $(3,4,12)$. Up to now these enzymes have not been isolated and characterized biochemically, but several data indicate that they are complex type I restriction endonucleases (combined with DNA-adenine methylases [3-6, 12; N. E. Murray, J. A. Gough, B. Suri, and T. A. Bickle, Eur. Mol. Biol. Org. J., in press]).

When cells of Escherichia coli B or K are infected by bacteriophage $\mathrm{T} 3$ or $\mathrm{T} 7$, the phagecoded $\mathrm{ocr}^{+}$protein (gp 0.3) blocks the type I restriction systems of the host cells and thereby prevents both DNA cleavage and methylation (for a review, see reference 7). The ocr $^{+}$gene function is also capable of inhibiting the endonucleolytic and methylating activities of type III restriction enzymes (e.g., EcoP1 [9]); however, type II endonucleases are affected neither in vivo (D. H. Krüger et al., manuscript in preparation) nor by the purified ocr $^{+}$protein in vitro (10; Krüger et al., in preparation).
We have now examined the effect of $\mathrm{ocr}^{+}$on the action of the SA and SB DNA host specificity systems of $S$. typhimurium. Since T3 and T7 generally do not adsorb to Salmonella cells (2), we used the following $E$. coli strains into which the SA, SB, or both host specificity genes had been introduced by Van Pel and Colson (12) through conjugation with $S$. typhimurium $\mathrm{Hfr}$ cells: strain 4614 (WA3703) $\left(\mathrm{SA}^{+} \mathrm{SB}^{+}\right)$, strain 4619 (WA3704) $\left(\mathrm{SA}^{+} \mathrm{SB}^{-}\right.$), strain 4620 (WA3705) $\left(\mathrm{SA}^{-} \mathrm{SB}^{+}\right.$), and strain 4621 (WA3706) $\left(\mathrm{SA}^{-} \mathrm{SB}^{-}\right)$.

Table 1 shows the growth data for $\mathrm{T} 3$ and $\mathrm{T} 7$ $\mathrm{ocr}^{+}$and $\mathrm{ocr}$ derivatives in the various hosts. Whereas the replication of $\mathrm{ocr}^{+}$strains was not inhibited by the $\mathrm{SA}$ and $\mathrm{SB}$ systems, $\mathrm{SA}^{+}$ strains reduced the efficiency of plating (EOP) of the phage T3 ocr mutant T3/R7 fivefold, and $\mathrm{SB}^{+}$restricted the phage T7 ocr mutant T7/D111 30-fold. Phage adsorption was not affected (data not shown).

The ocr phages subject to restriction could also be host-specifically modified by the $\mathrm{SA}^{+}$ and $\mathrm{SB}^{+}$systems (Table 2 ). It should be pointed

TABLE 1. Growth of T3 and T7 phage and their ocr mutants on host strains with Salmonella SA and SB DNA restriction systems

\begin{tabular}{|c|c|c|c|c|c|c|}
\hline \multirow[b]{2}{*}{ Phage $^{a}$} & \multirow{2}{*}{$\begin{array}{c}\text { Gene } 0.3 \\
\text { function } \\
\text { of phage }{ }^{b}\end{array}$} & \multicolumn{5}{|c|}{ Relative $\mathrm{EOP}^{c}$ on $E$. coli strain: } \\
\hline & & $\begin{array}{l}\text { WA921 } \\
\left(E_{\text {coK }}^{-}\right)\end{array}$ & $\begin{array}{c}\text { WA3703 } \\
\left(\mathrm{SA}^{+} \mathrm{SB}^{+}\right)\end{array}$ & $\begin{array}{c}\text { WA3704 } \\
\left(\mathrm{SA}^{+} \mathrm{SB}^{-}\right)\end{array}$ & $\begin{array}{c}\text { WA3705 } \\
\left(\mathrm{SA}^{-} \mathrm{SB}^{+}\right)\end{array}$ & $\begin{array}{c}\text { WA3706 } \\
\left(\mathrm{SA}^{-} \mathrm{SB}^{-}\right)\end{array}$ \\
\hline$\overline{\text { T3 }}$ & ocr $^{+}$ & 1 & 1 & 1 & 1 & 1 \\
\hline $\mathrm{T} 3 \mathrm{sam}{ }^{-}$ & ocr ${ }^{+}$ & 1 & 1 & 1 & 1 & 1 \\
\hline $\mathrm{T} 3 / \mathrm{R} 7$ & ocr & 1 & $2 \times 10^{-1}$ & $2 \times 10^{-1}$ & 1 & 1 \\
\hline T7 & $\mathrm{ocr}^{+}$ & 1 & 1 & 1 & 1 & 1 \\
\hline T7/D111 & ocr & 1 & $3 \times 10^{-2}$ & 1 & $3 \times 10^{-2}$ & 1 \\
\hline Lambda (control) & & 1 & $3 \times 10^{-6}$ & $3 \times 10^{-5}$ & $3 \times 10^{-4}$ & 1 \\
\hline
\end{tabular}

\footnotetext{
${ }^{a}$ Phage were grown on E. coli WA921 ( $h s d R$ hsdM).

${ }^{b}$ For the characterization of the phage derivatives used here, see reference 8.

c Relative EOP values (determined in parallel) are the ratios of titers on test indicator strains to titers on permissive strain WA921. All incubations were at $30^{\circ} \mathrm{C}$ (4).
} 
TABLE 2. Host-dependent modification of ocr phage by Salmonella systems ${ }^{a}$

\begin{tabular}{|c|c|c|c|c|c|}
\hline \multirow[b]{2}{*}{ Phage (strain) } & \multicolumn{5}{|c|}{ Relative $\mathrm{EOP}^{b}$ on $E$. coli strain: } \\
\hline & $\begin{array}{l}\text { WA921 } \\
\left(E^{\prime} c o K^{-}\right)\end{array}$ & $\begin{array}{c}\mathrm{WA3703}_{\left(\mathrm{SA}^{+} \mathrm{SB}^{+}\right)}\end{array}$ & $\begin{array}{c}\text { WA3704 } \\
\left(\text { SA }^{+} \text {SB }^{-}\right)\end{array}$ & $\begin{array}{c}\text { WA3705 } \\
\left(\mathrm{SA}^{-} \mathrm{SB}^{+}\right)\end{array}$ & $\begin{array}{c}\text { WA3706 } \\
\left(\mathrm{SA}^{-} \mathrm{SB}^{-}\right)\end{array}$ \\
\hline T3/R7 (WA921) & 1 & $2 \times 10^{-1}$ & $2 \times 10^{-1}$ & 1 & 1 \\
\hline T3/R7 (WA921, WA3704) & 1 & $7 \times 10^{-1}$ & $7 \times 10^{-1}$ & 1 & 1 \\
\hline T3/R7 (WA921, WA3704, WA3706) & 1 & $2 \times 10^{-1}$ & $2 \times 10^{-1}$ & 1 & 1 \\
\hline T7/D111 (WA921) & 1 & $3 \times 10^{-2}$ & 1 & $3 \times 10^{-2}$ & 1 \\
\hline T7/D111 (WA921, WA3705) & 1 & $6 \times 10^{-1}$ & 1 & $6 \times 10^{-1}$ & 1 \\
\hline T7/D111 (WA921, WA3705, WA3706) & 1 & $3 \times 10^{-2}$ & 1 & $3 \times 10^{-2}$ & 1 \\
\hline
\end{tabular}

${ }^{a}$ Single plaques grown on the indicated host strains were dispersed in phage buffer; suitable dilutions of phage were mixed with the respective host indicator cells and overlay agar and poured into petri dishes containing basal agar. All phage propagations were performed in nutrient broth medium at $30^{\circ} \mathrm{C}$.

${ }^{b}$ See Table 1, footnote $c$.

out that host-modified ocr phages escaped restriction to an appreciable degree when replated on the same host; however, the EOP never reached unity (Table 2). (Incomplete modification of ocr phages has also been described for $E c o B$ and $E c o K$; this could be the consequence of incomplete methylation of the phage DNA [8, 11].) The modification effect was fully reversible, i.e., it disappeared after passage over a restriction-negative host strain (Table 2).

To demonstrate the degradation of ocr phage DNA in the restricting host cells, we labeled phage T7/D111 with $\left[{ }^{3} \mathrm{H}\right]$ thymidine during propagation in a modification-negative host strain and used the purified phage to infect $E$. coli WA3705 $\left(\mathrm{SB}^{+}\right)$. The increase of acid-soluble radioactivity in the restricting host compared with that in appropriate controls showed that DNA restriction of ocr phage was taking place (Fig. 1).

Brunovskis and Burns (2) reported on the DNA restriction of wild-type T7 in S. typhimurium 409 cells. If these results prove to be reproducible (they are difficult to interpret because impaired phage adsorption and intracellular restriction are not kept apart, and the differentiation between "mutated" and "modified" phage is insufficient), they represent a restriction system that is independent of $\mathrm{SA}$ and $\mathrm{SB}$ and attacks T7 DNA in vivo.

Our data show that the $\mathrm{ocr}^{+}$gene function of phages $\mathrm{T} 3$ and $\mathrm{T} 7$ is capable of protecting phage DNA from the effects of the $S$. typhimurium host specificity systems SA and SB. The ocr mutants are restricted and modified in vivo. The role of $\mathrm{ocr}^{+}$-mediated protection is most obvious in $\mathrm{SB}^{+}$cells infected with phage $\mathrm{T} 7$ compared with its ocr mutant T7/D111. The T7 genome apparently does not contain recognition sites for the SA system, since T7/D111 was not restricted in $\mathrm{SA}^{+}$cells. With the phage $\mathrm{T} 3$ ocr mutant T3/R7, there was restriction by the $\mathrm{SA}^{+}$but not by the $\mathrm{SB}^{+}$system. The closely related phages $\mathrm{T} 3$ and
T7 seem to possess different numbers of SA- and SB-specific recognition sites in their genomes. Such differences between T3 and T7 DNA in the number and localization of recognition sites for restriction enzymes have also been reported for other endonucleases, e.g., AvaI, HindIII, KpnI,

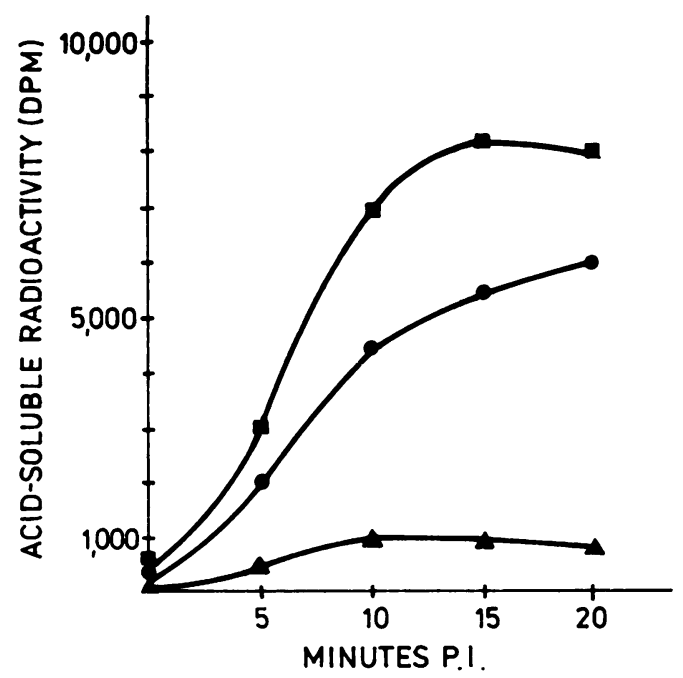

FIG. 1. DNA breakdown of $\left[{ }^{3} \mathrm{H}\right]$ thymidine-labeled phage T7/D111 (ocr) in E. coli WA3705 $\left(\mathrm{SB}^{+}\right)$cells. $\left[{ }^{3} \mathrm{H}\right]$ DNA-labeled phage were grown as described (8). Logarithmically dividing cells were concentrated to a titer of $10^{9}$ cells per $\mathrm{ml}$, infected with 0.1 phage per cell, and incubated at $30^{\circ} \mathrm{C}$. At the indicated times, 0.9 $\mathrm{ml}$ of the infected mixture was added to $0.1 \mathrm{ml}$ of icecold $50 \%$ trichloroacetic acid. After $30 \mathrm{~min}$ in an ice bath, the samples were spun in an Eppendorf centrifuge, and the acid-soluble radioactivity contained in the supernatant was counted. The total radioactivity of phage DNA in a $0.9-\mathrm{ml}$ sample was $18,000 \mathrm{dpm}$; nearly $65 \%$ of the phage $(12,000 \mathrm{dpm})$ adsorbed to the cells after $5 \mathrm{~min}$. The specific radioactivity of the phage was $2 \times 10^{-4} \mathrm{dpm} /$ PFU. Infection of $E$. coli strains WA921 ( $h s d R$ hsdM) (A), WA3705 $\left(\mathrm{SB}^{+}\right)(\mathrm{O})$, and WA960 $\left(E c o B^{+}\right)(\square)$ with phage T7/D111. P.I., Postinfection. 

MboI, XbaI (1), and $E c o R V$ (D. H. Krüger et
al., in preparation).

We thank $W$. Arber (Basel) for providing the bacterial strains with different DNA host specificities and F. W. Studier (Upton, N.Y.) and R. Hausmann (Freiburg i.Br.) for phage mutants. We thank Cornelia Schroeder (Berlin) for stimulating discussions and help in preparing the manuscript, T. A. Bickle (Basel) for critical reading of the manuscript, and H. A. Rosenthal (Berlin) for the support of our studies.

\section{LITERATURE CITED}

1. Bailey, J. N., D. R. Dembinski, and W. T. McAllister. 1980. Derivation of a restriction map of bacteriophage $T 3$ DNA and comparison with the map of bacteriophage $T 7$ DNA. J. Virol. 35:176-183.

2. Brunovstis, I., and R. O. Burns. 1973. Growth of coliphage T7 in Salmonella typhimurium. J. Virol. 11:621629.

3. Bullas, L. R., C. Colson, and B. Neufeld. 1980. DNA restriction and modification systems in Salmonella: chromosomally located systems of different serotypes. J. Bacteriol. 141:275-292.

4. Colson, C., and A. Van Pel. 1974. DNA restriction and modification systems in Salmonella I. SA and SB, two $S$. typhimurium systems determined by genes with a chromosomal location comparable to that of $E$. coli hsd genes. Mol. Gen. Genet. 129:325-337.
5. Gomez-Eichelmann, M. C. 1979. DNA adenine and cytosine methylation in Salmonella typhimurium and Salmonella typhi. J. Bacteriol. 140:574-579.

6. Hattman, S., S. Schlagman, L. Goldstein, and M. Fröhlich. 1976. Salmonella typhimurium SA host specificity system is based on deoxyribonucleic acid-adenine methylation. $\mathrm{J}$. Bacteriol. 127:211-217.

7. Krüger, D. H., and C. Schroeder. 1981. Bacteriophage T3 and bacteriophage $T 7$ virus-host cell interactions. Microbiol. Rev. 45:9-51.

8. Krüger, D. H., C. Schroeder, S. Hansen, and H. A. Rosenthal. 1977. Active protection by bacteriophages T3 and $\mathrm{T} 7$ against $E$. coli $\mathrm{B}$ - and $\mathrm{K}$-specific restriction of their DNA. Mol. Gen. Genet. 153:99-106.

9. Krïger, D. H., M. Reuter, S. Hansen, and C. Schroeder. 1982. Influence of bacteriophage $\mathrm{T} 3$ and $T 7$ gene functions on a type III (EcoP1) DNA restriction-modification system in vivo. Mol. Gen. Genet. 185:457-461.

10. Mark, K. K., and F. W. Studier. 1981. Purification of the gene 0.3 protein of bacteriophage $\mathrm{T} 7$, an inhibitor of the DNA restriction system of $E$. coli. J. Biol. Chem. 256:000-000.

11. Studier, F. W. 1975. Gene 0.3 of bacteriophage T7 acts to overcome the DNA restriction system of the host. J. Mol. Biol. 94:283-295.

12. Van Pel, A., and C. Colson. 1974. DNA restriction and modification systems in Salmonella II. Genetic complementation between the $\mathrm{K}$ and $\mathrm{B}$ systems of $E$. coli and the $S$. typhimurium system SB, with the same chromosomal location. Mol. Gen. Genet. 135:51-60. 